Karolina MESSYASZ

Uniwersytet Łódzki

karolina.messyasz@gmail.com

\title{
DYSKURS MEDIALNY I POLITYKA WOBEC MŁODZIEŻY A JEJ SPOŁECZNE REPREZENTACJE
}

\begin{abstract}
Media discourse, policy towards youth and its social representations
The article attempts to trace the discourse of the press about youth from the perspective of twenty years of transition appearing in media communications by „Gazeta Wyborcza”, „Dziennik. Polska-Europa-Świat”, „Tygodnik Powszechny” and „Przegląd Polityczny”. Discursive construction of reality is treated as a social activity. Symbolic activity understood as ways of defining reality for young people, is, in my opinion, a key to try to answer questions about youth identity, position and role in the social world. Analysis were based on eight debates with the participation of young people. The analysis allowed to reconstruct a complete pictures of each debate, which were then presented in the form of graphic diagrams. It helped to restore the views of young people, the world around them, their place in it, subject of their concerns, fears, anxieties, dreams, life goals, values, etc. What is more, that knowledge reveal four collective representation of youth: "Generation '68", "Generation '89", “Generation 2000", "Generation 2010": and conditions under which they were created. Analysis are testimony to the progressive deconstruction of cultural tools, by which young people could define themselves in terms of a community. As a result, in discourse there appear a pragmatic and individualistic attitudes to reality and materialization of the awareness of young people.
\end{abstract}

Keywords: discourse, policy, youth, social representations, generation

Słowa kluczowe: dyskurs, polityka, młodzież, społeczna reprezentacja, pokolenie 


\section{WPROWADZENIE}

W artykule wychodzę od przekonań, na których zbudowana jest teoria społecznych reprezentacji rzeczywistości. Odnosi się ona do konstruktu wyjaśniającego źródła oraz charakter samowiedzy członków społeczeństwa. O ile jej genezy należy upatrywać w różnych obiegach komunikacyjnych, o tyle treść samowiedzy jest standaryzowana do formatu podobnego stereotypom. Do obiegów tych zaliczyć można zarówno środowiska socjalizacji pierwotnej, grupy zawodowe, wspólnoty lokalne, dyskurs elit symbolicznych, jak i szeroko definiowany dyskurs medialny.

Analizy organizacji życia społecznego odnoszące się do kultury cywilizacji zachodniej pozwalają zaobserwować wzrost znaczenia, a także większą wyrazistość kategorii młodości. Staje się ona poniekąd centralną kategorią wyjaśniającą, ze względu na swoją funkcjonalność w obszarach gospodarki, polityki i kultury. Tym samym nie mniej istotną kategorię wyjaśniającą i wyjaśnianą stanowi sama młodzież. Na łamach prasy staje się ona nie tylko przedmiotem, ale również podmiotem dyskursu, będąc jedną $\mathrm{z}$ jego stron.

Kształtowanie się narracji tożsamościowych szerokiej kategorii społecznej, jaką stanowi młodzież, opiera się - w moim przekonaniu - na procesach analogicznych do opisywanych przez teorie społecznych reprezentacji. Pytając o medialne obrazy młodzieży, zadajemy jednocześnie pytania o to, jak duża część samowiedzy kreowana jest z udziałem mediów masowych oraz na ile stanowi ona determinantę całościowego sposobu myślenia o swoim miejscu w systemie organizacji społecznej. Waga „dyskursowego" spojrzenia staje się tym większa, im mocniej uświadomimy sobie, jak często ci sami młodzi ludzie, wychowani przecież już w społeczeństwie zmedializowanym, mylą medialny obraz świata ze światem rzeczywistym.

Przeprowadzone przeze mnie analizy, stanowiące sedno dysertacji doktorskiej, będąc próbą charakterystyki obecności młodych ludzi w polskim dyskursie prasowym, mają służyć rekonstrukcji i ujawnieniu pewnego obszaru wiedzy dotyczącej współczesnej młodzieży polskiej. Obecność ta, przy odpowiednich zastrzeżeniach, może stanowić swego rodzaju medialne lustro rzeczywistego miejsca i znaczenia młodzieży polskiej po 1989 r. Kontekstem zatem był szczególnie ważny i dynamiczny okres 20-letniej transformacji ustrojowej w Polsce.

Podstawę części empirycznej stanowi analiza dyskursu prasowego, a dokładnie analiza debat, które odbywały się z udziałem młodzieży na łamach dzienników, tygodników, kwartalników. Celem tak pomyślanych badań była drobiazgowa rekonstrukcja zakresu i rodzajów treści, którymi te debaty są wypełniane przez współczesną polską młodzież. Dzięki wykorzystaniu analizy dyskursu jako metody wraz z towarzyszącymi jej narzędziami w postaci presupozycji, rematów, mechanizmów dyskursywnych, praktyk sepizacyjnych, implikatur i rodzajów argumentacji, możliwe stało się odtworzenie wiedzy o tym, jaka jest treść reprezentacji medialnych oraz dyskursywnych warunków ich powstawania. Wielostopniowa analiza kolejnych cząstkowych charakterystyk dyskursu prasowego dotyczącego młodzieży pozwoliła na rekonstrukcję pełnego obrazu 
każdej debaty. W rezultacie otrzymujemy odpowiedzi na pytanie o możliwość wspólnoty dyskursu młodzieży i o młodzieży, który konstytuowałby zręby jej tożsamości, świat jej przedmiotów i nadawanych mu znaczeń oraz charakterystyczne dla niej wzory komunikacji stanowiące podstawę dla procesów tworzenia uwspólnionych interpretacji rzeczywistości.

\section{ZAŁOŻENIA TEORETYCZNE}

Dla właściwego odczytania przeprowadzonych analiz kluczowym elementem staje się wskazanie fundamentalnych założeń o charakterze ontologicznym, stanowiących punkt wyjścia dla prezentowanej pracy. Pierwszą przesłanką jest przekonanie o rudymentarnie językowym charakterze rzeczywistości społecznej. Zgodnie z nim język pełni kluczową rolę w tworzeniu i porządkowaniu świata społecznego. Staje się on konstytutywny dla istnienia społecznego świata. Nabiera to szczególnej wyrazistości we współczesności, którą charakteryzuje znaczące u j ę z y kow i e n i e. Współczesność produkuje bowiem teksty na skalę masową. Tekst rozumiany jako przekaz staje się immanentną częścią świata ludzkiego, jednym z jego głównych wytworów. Dlatego też lepsze zrozumienie języka, którym się posługujemy, może prowadzić do lepszego zrozumienia społecznych problemów wyróżniających społeczeństwa późnej nowoczesności.

Ponadto dynamiczny rozwój środków masowego przekazu i rosnąca rola zapośredniczonego doświadczania rzeczywistości powodują wzrost znaczenia komunikowania społecznego i dyskursywnego jej konstruowania. Wobec tego jesteśmy poniekąd skazani na jej medialne interpretacje, wynikające z centralnego znaczenia mediów w symbolicznym kształtowaniu rzeczywistości społecznej. W rezultacie tych przemian wyłonił się typ społeczeństwa nazwany przez socjologów społeczeństwem informacyjnym, dla którego konstytutywnym elementem jest istnienie sfery publicznej opartej na konwersacyjnych formach działania. Wszystko to doprowadziło do zwiększenia zainteresowania obszarem wytwarzania rozmaitych dyskursów. Nie ulega wątpliwości, że obecnie mamy do czynienia z d y s ku r s y w i z a cj ą współczesnego świata, która [...] dotyczy zarówno świata prywatnych kontaktów, jak iświata publicznego. Jeden i drugi to uniwersum nieustannego informowania $i$ komentowania, przekonywania $i$ uzgadniania ${ }^{1}$. To w sferze dyskursu dochodzi do gry różnych podmiotów społecznych i walki o obywatela. Na tej właśnie płaszczyźnie różne podmioty prezentują własne światopoglądy, opinie czy koncepcje rzeczywistości, mające służyć przekonaniu odbiorców komunikatów do pewnej wizji ładu społecznego.

Zgodnie z drugim podstawowym założeniem, media, stanowiąc jedno z głównych źródeł informacji, nie tylko pokazują i opisują świat, ale również w pewien sposób go kreują, hierarchizują oraz podpowiadają interpretacje bieżących wydarzeń. Odzwierciedlają, ale mają zarazem możliwość tworzenia relacji władzy i podporządkowania. Zatem dyskurs prasowy, będący przedmiotem niniejszych analiz, nie jest neu-

I. Krzemiński, Socjologiczne przemiany wspótczesnego świata, [w:] Socjologia a przemiany wspótczesnego świata, red. tenże, Warszawa 2004, s. 21-22. 
tralnym nośnikiem; jest mocno uwarunkowany historycznie, społecznie i kulturowo, podlega konkretnej sytuacji komunikacyjnej i kontekstowi, w którym ta sytuacja zachodzi. Ma także szerokie możliwości normalizacji stworzonej przez siebie wizji świata, choćby przez masowość odbioru. Wobec tego prasa jest przestrzenią kształtowania społecznego wyobrażenia o położeniu młodzieży. Społeczne reprezentacje młodzieży, by użyć terminu Serga Moscoviciego ${ }^{2}$, powstają w dużej mierze w wyniku percepcji komunikatów dotyczących młodzieży, niekoniecznie jej autorstwa.

Wzrostowi znaczenia procesów komunikacji towarzyszy dodatkowo, jak pisze Anthony Giddens, wzrost refleksyjności, a co za tym idzie: sproblematyzowania postindustrialnych społeczeństw. Pociąga to za sobą odmienne strategie budowania jednostkowej i zbiorowej tożsamości, a także konstruowania społecznej struktury. Refleksyjność zakłada bowiem uregulowane wykorzystywanie wiedzy o warunkach życia społecznego jako konstytutywny element jego organizacji i przekształcania przez społecznych aktorów ${ }^{3}$. W przypadku młodzieży oznaczać to będzie, że jej społeczne reprezentacje powstają w dużej mierze w wyniku percepcji komunikatów uniwersalizowanych i naturalizowanych w mediach przez przedstawicieli elit symbolicznych: ekspertów, polityków, naukowców, dziennikarzy itd. Treść tych komunikatów jest natomiast silnie nacechowana kontekstowo, co w przypadku Polski oznacza, że dyskurs medialny wobec młodych, jak i przez nich samych reprezentowany, nosi znamiona dwóch ważnych procesów: transformacji ustrojowej oraz neoliberalnej globalizacji.

\section{KONTEKST SPOŁECZNY I SPECYFIKA SYTUACJI MŁODZIEŻY}

Transformacja ustrojowa to jedna z głównych perspektyw analizy i wyjaśniania przemian polskiego społeczeństwa. Wielowymiarowe przeobrażenia społeczne dokonywały się w kontekście przejścia od ładu monocentrycznego do policentrycznego, od socjalizmu do demokracji oraz od gospodarki centralnie planowanej do kapitalizmu. Wydaje się, że wraz z ugruntowaniem się demokracji, co najmniej w wymiarze proceduralnym $\mathrm{i}$ instytucjonalnym, paradygmat transformacyjny traci na znaczeniu na rzecz wchodzenia w system globalnej gospodarki określany mianem kapitalizmu postindustrialnegó .

Bardzo istotnym uczestnikiem tych przemian była młodzież. To właśnie temu aktorowi społecznemu przypada najczęściej w udziale rola siły napędowej, dynamizują-

2 S. Moscovici, The Phenomenon of Social Representations, [w:] Social Representations, eds. R. M. Farr, S. Moscovici, Cambridge-New York-Paris 1984; S. Moscovici, Social Representations: Explorations in Social Psychology, ed. G. Duveen, New York 2001.

3 A. Giddens, Stanowienie spoteczeństwa. Zarys teorii strukturacji, przeł. S. Amsterdamski, Poznań 2003; A. Giddens, Nowoczesność i tożsamość. "Ja” i spoteczeństwo w epoce późnej nowoczesności, przeł. A. Szulżycka, Warszawa 2006, Biblioteka Socjologiczna; U. Beck, A. Giddens, S. Lash, Modernizacja refleksyjna, przeł. J. Konieczny, Warszawa 2009, Socjologia Wspótczesna - Wydawnictwo Naukowe PWN.

4 M.Ziółkowski, Globalizacja a przemiany struktury spotecznej we wspótczesnej Polsce, [w:] Spoteczne problemy globalizacji, red. nauk. Z. Blok, Poznań 2001, s. 18, Cztowiek i Spoteczeństwo - Uniwersytet im. Adama Mickiewicza w Poznaniu. Wydziat Nauk Spotecznych, t. 19. 
cej procesy zmian społecznych, rola innowatora. To w młodych ludziach upatruje się potencjał rozwojowy każdego społeczeństwa ${ }^{5}$ Z podobną sytuacją mieliśmy do czynienia w Polsce na początku lat 90. To właśnie młodzi ludzie stali się w większości beneficjentami nowego ustroju i rodzącego się kapitalistycznego rynku pracy. Pokolenie, które wówczas doświadczyło bezprecedensowego awansu, stało się na długo wyznacznikiem standardu, do którego aspirowały kolejne roczniki. Niestety, proces transformacji nie był wyłącznie czasem prosperity i nie wszyscy przedstawiciele tej generacji byli jego beneficjentami. Ślady tego odnaleźć można w narracjach młodych ludzi, które, zebrane w formie debat, stanowią źródło wiedzy o percepcji zmieniających się warunków społeczno-ekonomicznych, jak i politycznych.

Ostatnie 20-lecie można podzielić na trzy etapy. Pierwszą fazę transformacji charakteryzowało epatowanie ideologią sukcesu i wielkimi możliwościami, jakie otworzyły przed ludźmi demokracja i kapitalizm. Zmiana ustrojowa pociągnęła za sobą radykalne zmiany na rynku pracy, w sferze konsumpcji, komunikacji, technologii i techniki. Młodzi Polacy bardzo szybko stali się „dziećmi nowego systemu”, współtwórcami rzeczywistości rynkowej, właśnie dzięki swoim naturalnym predyspozycjom, takim jak potencjał, dynamizm, kreatywność, przedsiębiorczość, optymizm itd. Tylko ta grupa była w stanie, często bez doświadczenia i wyższego wykształcenia, ale wykazując niezwykły pragmatyzm, nadążyć za dokonującymi się zmianami. Dało im to wyjątkową okazję do indywidualnego awansu społecznego i materialnego sukcesu. Ten czas to lata 1992-1997, co obrazuje też poniższy wykres. Okres ten znamionują spadająca - mimo że początkowo wysoka - stopa bezrobocia oraz rosnący poziom PKB.

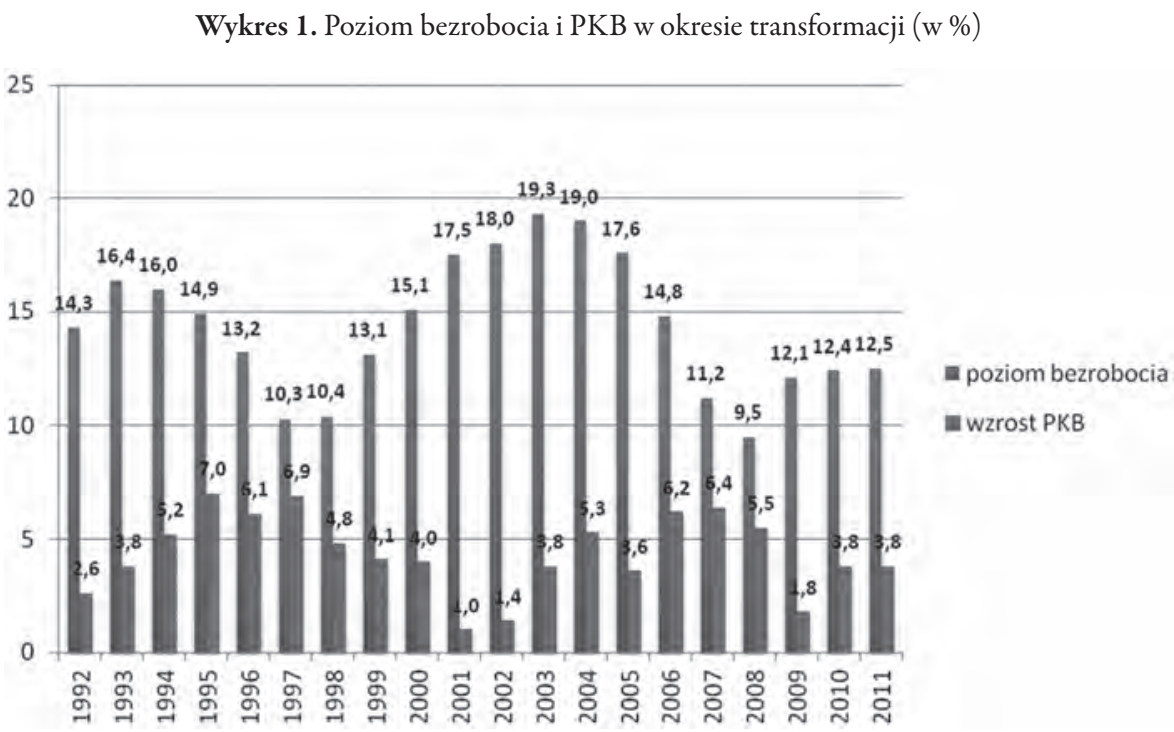

Źródło: opracowanie własne na podstawie danych GUS.

5 K. Mannheim, The Problem of Generations, [w:] tenże, Essays on the Sociology of Knowledge, New York 1952. 
Druga faza transformacji (1998-2003) podlega mniej dynamicznym i mniej oczywistym zmianom. Sytuacja gospodarcza kraju zaczęła się pogarszać. Drastycznie rosnące bezrobocie, sięgające prawie $20 \%$, oraz spadający do $1 \%$ poziom PKB to świadectwo najgorszych wyników polskiej gospodarki w okresie transformacji. Tymczasem młodzi ludzie epatowani przez sukces swoich poprzedników oraz płynącą zewsząd narrację o możliwości awansu przez edukację, wykazywali coraz wyższe aspiracje edukacyjne i statusowe (zob. wykres 2). Byli coraz silniej socjalizowani do wartości, jaką jest indywidualny sukces, oraz do konsumpcyjnego stylu życia. Jednocześnie zaczęli boleśniej zderzać się z niewydolnością systemu, szczególnie na rynku pracy. Kryzys, który dotarł do Polski w latach 2000-2002, spowodował, że młodzi i wykształceni ludzie stawali się ofiarami bezrobocia. Odzwierciedlają to także oceny sytuacji w kraju przez młodzież. $\mathrm{Na}$ pytanie o to, w jakim kierunku zmierza sytuacja, odpowiedź $w$ dobrym w $1998 \mathrm{r}$. wybrało 46\% młodych respondentów, zaś w 2003 r. tylko 21\%; na odpowiedź $w$ ztym wskazała w 1998 r. $1 / 4$ badanych (26\%), a w 2003 r. ponad połowa (54\%). Rok 2003 to także radykalnie wysoki poziom niezadowolenia młodych z funkcjonowania demokracji w naszym kraju $-67 \%$. Dane te obrazują, jak duży wpływ na oceny respondentów ma kontekst w postaci sytuacji gospodarczej, która dodatkowo przekłada się na krytycyzm wobec wymiaru polityki.

Wykres 2. Procent osób z wyższym wykształceniem7 (w\%)

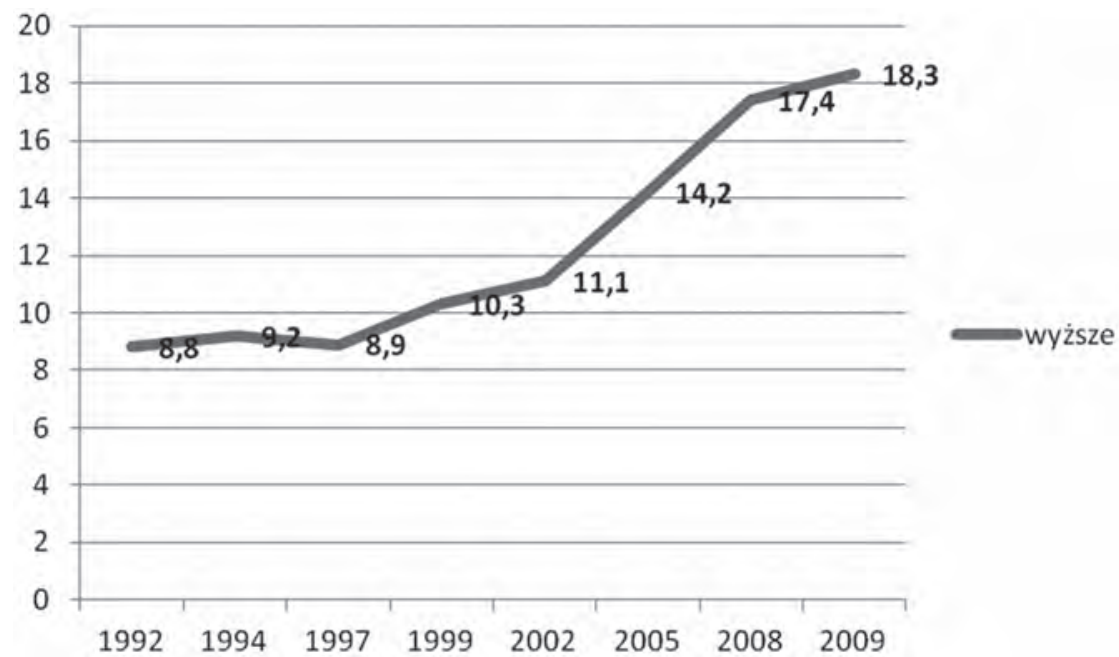

Źródło: opracowanie własne na podstawie danych GUS pochodzących z Rocznika demograficznego 2010; H. Domański, Merytokracja w zasadach dystrybucji wynagrodzeń w latach 1982-2005, [w:] Zmiany stratyfikacji spotecznej w Polsce, red. tenże, Warszawa 2008.

Mtodzież 2003, „Opinie i Diagnozy” 2004, nr 2.

Dane z lat 1992-1999 pochodzą z: H. Domański, Merytokracja w zasadach dystrybucji wynagrodzeń w latach 1982-2005, [w:] Zmiany stratyfikacji spotecznej w Polsce, red. tenże, Warszawa 2008. Dane z lat 2002-2009 pochodzą z Rocznika demograficznego 2010, s. 157. 
Trzecia faza transformacji to lata 2004-2008, cechujące się spadającym wskaźnikiem bezrobocia (o prawie 10 punktów procentowych), wahającym się poziomem $\mathrm{PKB}$, choć dość wysokim średnim jego poziomem w całym pięcioleciu. Mamy zatem do czynienia, po okresie kryzysu, z ponownym wzrostem gospodarczym. Znajduje to odzwierciedlenie w ocenach ustroju. W 2003 r. 31\% badanych uznało, że demokracja ma przewagę nad innymi formami rządów, natomiast w $2008 \mathrm{r}$. takiej oceny dokonało $34 \%$ respondentów. Spadła natomiast liczba osób wskazujących, że niekiedy rządy niedemokratyczne mogą być bardziej pożądane niż rządy demokratyczne; z 23\% w $2003 \mathrm{r}$. do $20 \%$ w 2008 r. ${ }^{8}$ W tym czasie coraz bardziej widoczne zaczynają być wzmacniające się wpływy ideologii indywidualizmu wśród młodych ludzi. W latach 2003-2008 odsetek osób uważających, że sukces w życiu zależy przede wszystkim od indywidualnych predyspozycji, wzrósł o 6 punktów procentowych (z 71\% do 77\%). Znacznie większy wzrost odnotowano w przypadku pytania o stosunek do pozycji społecznej własnego pokolenia: w $2008 \mathrm{r}$. aż $3 / 4$ młodych (75\%) uznało, że przed ich pokoleniem stoi szansa na lepsze życie niż przed pokoleniem rodziców - wzrost o 19 punktów procentowych w stosunku do 2003 r. ${ }^{9} \mathrm{Na}$ ten czas przypada także zjawisko niezwykłej mobilizacji wyborczej młodego elektoratu z 2007 r., kiedy to 55,8\% mlodych w przedziale 18-25 lat oraz 62,5\% w wieku 26-35 lat wzięło udział w wyborach parlamentarnych i to głównie ich głosy zdecydowały o odsunięciu od władzy koalicji PiS-Samoobrona-LPR ${ }^{10}$.

Wydaje się, że rok 2008 stanowi swego rodzaju cezurę. Na niego przypada bowiem początek światowego kryzysu gospodarczego, ukazującego skutki globalizacji i wynikających z nich współzależności ekonomiczno-politycznych poszczególnych państw. Po raz pierwszy poniekąd skutków tych globalnych powiązań doświadczyła Polska. Mimo że wcześniej doświadczaliśmy już kryzysów gospodarczych, pierwszy raz przeżywamy go, będąc członkiem Unii Europejskiej, należąc do strefy Schengen i korzystając z otwartego rynku pracy. Można zatem powiedzieć, że - zgodnie z tezą Marka Ziółkowskiego - ostatnie 4 lata to czas coraz intensywniejszego wchodzenia w system gospodarki światowej, innymi słowy: postindustrialnego kapitalizmu. Na poziomie wskaźników makroekonomicznych mamy do czynienia ze wzrostem bezrobocia i mniej więcej stałym, choć różnie ocenianym przez ekonomistów poziomem PKB. Z jednej strony, jako nieliczni nie zanotowaliśmy recesji, a jedynie spowolnienie gospodarcze, z drugiej - następuje spadek realnej wartości dochodów i wzrost poziomu inflacji, co odbija się na kondycji gospodarstw domowych.

Sytuacja ta nie pozostaje bez wpływu na młode pokolenie. Oprócz kryzysu gospodarczego do warunków zastanych wyznaczających perspektywę życiową współczesnej młodzieży należą zjawiska konsumpcjonizmu i postpolityki. Współczesna kultura konsumpcji, czy też kultura konsumenta, to zjawisko rozległe i mające dalekosiężne skutki, wykraczające poza konsumpcję rozumianą jako wydatek pieniężny przeznaczony na dobra materialne lub usługi. Dziś wydatkowanie środków pieniężnych na skalę masową

8 Mtodzież 2003; Mtodzież 2008, „Opinie i Diagnozy” 2009, nr 13.

9 Mtodzież 2003; Mtodzież 2008.

10 Na podstawie danych z Polskiego Generalnego Sondażu Wyborczego. 
przez wszystkie klasy społeczne przekształca całą kulturę, stabilizuje sytuację społeczną i polityczną ${ }^{11}$. Za przykład może służyć Polska, która doświadczała dotychczas łagodniejszych skutków kryzysu między innymi dzięki wewnętrznemu popytowi. Niemniej jednak konsumpcjonizm to także oręż indywidualizmu, który przyczynia się do atomizacji społeczeństwa przez, używając metafory $\mathrm{C}$. Wright Millsa ${ }^{12}$, zamianę publicznych problemów na prywatne troski. W ten sposób mechanizm ten staje się swoistym wentylem bezpieczeństwa, niwelując choćby możliwość buntu ${ }^{13}$. Opisanym wyżej procesom sprzyja zjawisko postpolityki, które oznacza m.in. brak atrakcyjnych ideologii, które byłyby w stanie pociągnąc za sobą młodych ludzi, wyznaczając zbiorowe cele, i stanowić alternatywę dla indywidualnego budowania biografii. Widać to także w badaniach, które pokazują wyraźnie, że młodzi ludzie nie są zainteresowani sferą polityki. Dystans do polityki przejawia się niską frekwencją w wyborach, brakiem politycznych identyfikacji, niechęcią wobec zaangażowania w działalność polityczną oraz brakiem zaufania do polityków i partii politycznych.

Kryzys powoduje, że wykształcenie przestaje być gwarantem sukcesu. Jest to rzeczywistość absolwentów bez przysztości, jak określił rozczarowanych niemożliwością zaspokojenia swoich aspiracji młodych przedstawicieli klasy średniej Paul Mason ${ }^{14}$. Jest to w dużej mierze nie tylko kryzys teraźniejszości, ale kryzys perspektywy dla młodego pokolenia. Dobrze oddaje to krótki opis Zygmunta Baumana: [...] Jak tu przyjechatem, [do Anglii - przyp. K.M.] państwo utrzymywato studentów. Czesnego nie byto, ale za to byty stypendia, domy akademickie, starczato kieszonkowego nawet na przepisane przez nauczycieli ksiażki. Potem zastąiono to studenckimi "tanimi” kredytami: na razie ucz się, a potem sptacisz. To wtaśnie nazywam wprowadzeniem „życia na kredyt" do obowiazkowego programu nauczania. Pomyst ze studenckimi pożyczkami oparty byt zreszta na podobnie mylnej zasadzie co kredyty hipoteczne. Tam liczono, że ceny domów będa ciagle rosty, a tu, że ci z dyplomami dostana dobrze ptatne posady. Teraz widać, że tak wcale nie musi być. Już najbliższy rocznik brytyjskich absolwentów, z dtugami po uszy, może znaleźć się bez pracy ${ }^{15}$.

Jak zatem widać, w przypadku młodzieży przejście z systemu edukacji do systemu pracy, co stanowi też symboliczne przejście z młodości do dorosłości, jest mocno sprzęgnięte z możliwościami (kondycją) systemu społecznego. Ograniczone możliwości (w zakresie podaży miejsc pracy, mieszkań, satysfakcjonujących dochodów) stanowią zagrożenie opóźnionego wchodzenia w dorosłość. Coraz lepiej wykształceni i mobilni $\mathrm{z}$ trudnością znajdują pracę, co sprawia, że kłopoty związane z wchodzeniem w dorosłość stają się coraz powszechniejsze. W takich momentach konflikt, mający znamiona

11 T. Szlendak, Supermarketyzacja. Religia i obyczaje seksualne mtodzieży w kulturze konsumpcyjnej, Wrocław 2008, s. 6, Acta Universitatis Wratislaviensis, nr 3042.

12 C. Wright Mills, Wyobraźnia socjologiczna, przeł. M. Bucholc, red. nauk. i przedm. J. Mucha, Warszawa 2007, s. 55-62, Biblioteka Socjologiczna.

13 Jakże często dzisiaj zakupy służą do rozładowywania problemów i napięć.

14 P. Mason, Why It's Kicking Off Everywhere: the New Global Revolutions, London-New York 2012.

15 Z. Bauman, Koniec orgii, rozm. popr. T. Kwaśniewski, [w:] Twarze „Dużego Formatu”, Warszawa 2009, s. 12. 
prywatnego konfliktu pokoleń, nabiera cech konfliktu strukturalno-pokoleniowego, gdzie stronami nie są dorośli i młodzież, lecz młodzi (z ich niespełnionymi aspiracjami) i system społeczny ${ }^{16}$.

\section{DYSKURS MŁODZIEŻY W OKRESIE TRANSFORMACJI - REKONSTRUKCJA MEDIALNYCH OBRAZÓW ${ }^{17}$}

Po nakreśleniu kontekstu chciałabym przejść do prezentacji charakterystyki obecności młodych ludzi w polskim dyskursie prasowym. Celem analiz była rekonstrukcja dyskursywnych obrazów młodzieży, powiązanych z nimi zespołów przekonań normatywnych oraz warunków ich wytwarzania przez przeprowadzenie analizy tekstów autorstwa młodych osób, zebranych w formie debat prasowych, pojawiających się w przekazach medialnych „Gazety Wyborczej” (w latach 1996, 2002, 2004 i 2011), „Tygodnika Powszechnego” (2002), „Przeglądu Politycznego” (2004-2006) i „Dziennika. Polska-Europa-Świat" (2009). Podstawę części empirycznej stanowiło 8 debat z udziałem młodzieży. Zasadniczym przedmiotem badań empirycznych był dyskurs prasowy młodzieży polskiej realizowany w 3 uzupełniających się i zachodzących na siebie obszarach: (1) dyskurs młodzieży o sobie samej jako zbiorowości społecznej; (2) dyskurs młodzieży o rzeczywistości społecznej; (3) dyskurs dorosłych o młodzieży. Celem tak pomyślanych badań była drobiazgowa rekonstrukcja zakresu i rodzajów treści, którymi te debaty są wypełniane przez współczesną polską młodzież. Metodą, która posłużyła mi do tak zakrojonego celu, była analiza dyskursu.

Praca nad zebranym materiałem składała się z dwóch zasadniczych etapów. Pierwszym było poddanie każdego artykułu drobiazgowej analizie w wymiarach: językowym, komunikacyjno-interakcyjnym oraz poznawczym, polegającej na wskazaniu tematu wraz z wątkami pobocznymi, rematu, czyli najważniejszej części informacyjnej, własności dyskursowych, zabiegów retorycznych, presupozycji i implikatur. Narzędzia te służą wyrażaniu stosunku autorów do przedstawianych przez nich i innych uczestników debaty problemów, jak również wzmocnieniu zasadności i wiarygodności formułowanych w tekstach przekonań. Następnie na podstawie zbieżności narzędzi, jakimi posługiwali się autorzy tekstów (podobieństwa idiomu komunikacyjnego), zgłaszanych problemów, jak i sposobów ich wprowadzania do dyskusji, udało się wygenerować aktorów zbiorowych biorących udział w każdej debacie.

Drugi etap polegał na rekonstrukcji dyskursywnych obrazów młodzieży. Rekonstrukcja została dokonana w oparciu o wygenerowane w poprzednim etapie sposoby definiowania rzeczywistości przez młodzież oraz analizę elementów odnoszących się do wewnętrznej struktury i organizacji dyskursu (spójność dyskursu, związki międzydyskursowe, strategie dyskursywne, kontekst). Synteza wiedzy o obrazach mło-

16 K. Szafraniec, Mtodzi 2011, red. nauk. M. Boni, Warszawa 2011.

17 Ten fragment jest częścią wyników analizy zawartych w: K. Messyasz, Obrazy mtodzieży polskiej w dyskursie prasowym. Młodzież o sobie i rzeczywistości spotecznej, Łódź 2013. 
dzieży, odnosząca się do postawionych problemów badawczych, dotyczyła odpowiedzi na pytanie o możliwość wspólnoty dyskursu młodzieży i o młodzieży, który konstytuowałby zręby jej tożsamości, świat jej przedmiotów i nadawanych mu znaczeń, charakterystyczne dla niej wzory komunikacji stanowiące podstawę dla procesów tworzenia uwspólnionych interpretacji rzeczywistości.

W polskim dyskursie prasowym dotyczącym młodzieży w okresie transformacji ustrojowej wyróżnić można 4 obrazy: „Pokolenie “68”, „Pokolenie '89”, „Pokolenie 2000” oraz „Pokolenie 2010”. To właśnie te kategorie stanowią syntetyczną podstawę dla analizy odmiennych idiomów komunikacyjnych, którymi posługują się uczestnicy poszczególnych debat. Każdy z nich charakteryzuje się odmiennymi narzędziami językowymi, z pomocą których „praktykuje” różne sposoby definiowania rzeczywistości będące podstawą dla analizy „obrazów młodzieży”. Obrazy młodzieży są tutaj metaforami zmian zachodzących $w$ społeczeństwie polskim poddanym procesom gruntownej transformacji w wielu wymiarach życia społecznego. Natomiast etykiety „pokolenie” używam jako nazw własnych wyodrębnionych formacji dyskursywnych, korespondujących jednak z okresem adolescencji poszczególnych kohort.

\section{„POKOLENIE ‘68”}

Ta pierwsza pod względem chronologicznym generacja jako jedyna występuje w debatach wyłącznie z pozycji „dorosłych”, oceniających swoją szczególną rolę w pierwszych chwilach transformacji. Jej młodość przypadła na okres PRL-u, natomiast ze względu na niebagatelną rolę, jaką odegrała w procesie transformacji, jak również czynny udział w debatach, została umieszczona w rozpatrywanym kontekście. Stanowi także niezwykle ważny punkt odniesienia dla innych aktorów debat.

Potencjał dyskursywny „Pokolenia “68” zrealizował się, zdaniem uczestników całego badanego dyskursu, w publicznym praxis ładu społecznego III RP. Miejsce młodzieży z tego pokolenia opisywane jest jako obecność zauważalna, ekspansywna, wspólnotowa, zreifikowana w postaci przejęcia kontroli nad reprodukcją instytucjonalizującej się rzeczywistości publicznej i politycznej. Aksjonormatywny potencjał tego pokolenia został uwolniony do współkształtowania przestrzeni publicznej. Dla „Pokolenia '68” charakterystyczne jest, niekiedy egzaltowane, przekonanie o wyjątkowości więzi społecznych, o których można było powiedzieć, że dają podstawy dla wspólnotowego myślenia o uczestnictwie w życiu publicznym. Wyjątkowość ta brała się, zdaniem aktora, z rzeczywistej wspólnoty losu poddanego różnym formom opresji politycznej i kulturowej, ale przede wszystkim z umiejętności rezygnacji z osiągania celów partykularnych na rzecz wspólnotowego interesu zmiany porządku społeczno-politycznego. Idiom ten charakteryzuje się wybitnie paternalistyczną proweniencją; to główna cecha dystynktywna odróżniająca analizowane tutaj pokolenie od wszystkich pozostałych. Kolektywne reprezentacje rzeczywistości pojawiające się w „Pokoleniu “68” nabierały, jego zdaniem, mocy sprawczej właśnie dzięki ponadindywidualnemu wysiłkowi organizowania życia społecznego ku ponadindywidualnym celom. „Pokolenie “68”, jak 
każde inne wyróżnione w prowadzonych analizach, posiada ekskluzywne, przypisane wyłącznie sobie obszary, do których jest skłonne się odnosić i względem których ma określone, zbieżne postawy. W przypadku tej generacji nie bez znaczenia są oceny formułowane względem „Pokolenia '89”; stanowią one szczególnego rodzaju rewers tożsamości definiowanej pozytywnie. We własnym przekonaniu byli oni „ostatnim” pokoleniem, które potrafiło skorzystać z medium języka przeciwstawiającego się dominacji pieniądza i władzy oraz faworyzującego system socjokulturowy (rozumiany jako konglomerat społeczeństwa, religii, sztuki), w przeciwieństwie do następców.

\section{„POKOLENIE ‘89”}

Przedstawiciele „Pokolenia '89” we wszystkich analizowanych debatach eksponują dwa podstawowe elementy - rozczarowanie życiem publicznym III RP i satysfakcję, najczęściej umiarkowaną, z życia prywatnego. $\mathrm{Z}$ punktu widzenia statusu swojego języka publicznego, samoocena „Pokolenia '89” jest bardzo krytyczna. Jego rozczarowanie jest związane z brakiem możliwości zawiadywania procesami instytucjonalizacji życia społecznego, kulturowego, politycznego i gospodarczego na poziomie makro. Zablokowanie kanałów instytucjonalnego wpływu na kształtowanie życia publicznego oceniają jako konsekwencję polityki „Pokolenia ‘68”. Jednakże nie można omawianego aktora sklasyfikować jako jednoznacznie pozbawionego możliwości realizacji szans życiowych. Choć okoliczności systemowe w okresie liminalnym nie sprzyjały temu, by „Pokolenie '89" realizowało swoje idee w praxis życia politycznego, ważnym aspektem jego dyskursywnego potencjału okazują się możliwości kształtowania tej części rzeczywistości rynkowej, której wcześniej nie było; tym samym należało ją tworzyć ex nibilo. Komponowanie ładu rynkowego i demokratycznego na poziomie mezzo i mikro, zarówno w wymiarze organizacji i nadzoru instytucji, jak i miękkich elementów zarządzania nimi za pomocą reklamy, public relations i innych narzędzi marketingowych, dawało analizowanym aktorom wyjątkową okazję indywidualnego awansu społecznego i materialnego sukcesu. W tym aspekcie dyskursywna aktywność „Pokolenia '89” jest elementem procesu zmian istniejącej wcześniej struktury społecznej.

Cechą charakterystyczną dyskursu „Pokolenia “89” jest presuponowane przekonanie o wyższości wolnorynkowego ładu demokratycznego nad innymi modelami życia społecznego. Niekwestionowane dyskursywnie poparcie dla świata idei przekłada się w dyskursie „Pokolenia '89” na symboliczną legitymizację liberalnego systemu wartości, współbieżnego ze wspominanym modelem polityczno-gospodarczym. Co więcej, można tu wskazać na legitymizację przez dyskurs na wejściu systemu (input legitimation) w postaci przedzałożeń o wyższości liberalnego systemu wartości nad innymi, legitymizację w systemie (throughput legitimation), którego egzemplifikacją są rematy mnogości dróg awansu i możliwości wykorzystania szans życiowych, i legitymizację na wyjściu systemu (output legitimation) w postaci narracji o realizacji własnych projektów życiowych, będących syntezą aspiracji intelektualnych i materialnych. Te trzy aspekty procesu legitymizacji powodują, że w sposób szczególny zaczyna kształtować się aksjo- 
normatywna przestrzeń tożsamościowa „Pokolenia '89”, z postępującą mizerią wspólnotowości. Wzmiankowana powyżej liberalna formuła późnego kapitalizmu uwalnia media władzy i pieniądza spod medium języka; tym samym przestrzeń społecznych interakcji, w ramach której tworzy się wspólnotowa tożsamość, jest zapośredniczana przede wszystkim przez media instrumentalizujące prawie każdą aktywność nakierowaną na drugiego człowieka. Znaczenie przypisywane temu medium dzieli najliczniejszą grupę uczestników debaty na aktorów zadowolonych i niezadowolonych z praxis życia społecznego, a sposoby wartościowania tego medium pozwalają skategoryzować aktorów na zachwyconych materializmem i tych, którzy widzą w nim upadek zarówno oświeceniowego, jak i romantycznego modelu kultury.

\section{„POKOLENIE 2000”}

Zasadniczo, dwa krytyczne punkty w „biografii pokolenia” wyznaczone zostały symbolicznie przez rok 1974 oraz 1989. Obydwie cezury czasowe można uznać za momenty decydujące o formacyjnym kształcie „Pokolenia 2000”, który pozostawał całkowicie poza kontrolą jednostek wchodzących w jego skład. Przestrzeń tożsamościowa „Pokolenia 2000” rozciąga się od przyjęcia oczywistości i nieprzekraczalności rzeczywistości wolnorynkowej po potrzebę „tradycyjnych” (intelektualnych) wartości, których rodowód tkwi w aksjonormatywnym systemie reprezentowanym przez PRL-owską opozycję. Rozczarowanie, jakie przeżyło to pokolenie, którego początek przypadł właśnie na rok 2000, było konsekwencją stabilizacji ustroju demokratycznego w Polsce w latach 90., polegającej m.in. na nasyceniu dotychczas „młodego" rynku pracy oraz kanałów awansu społecznego w postaci szybkich i błyskotliwych karier „Pokolenia '89”. Lata 90. to również okres konsekwentnego budowania i socjalizowania młodych ludzi do mitu o „awansie przez edukację”, którego ofiarą już około 2000 r. padli absolwenci mający być jego pierwszymi beneficjentami. Dyskursywną obecność „Pokolenia 2000” wykuwającą się w przedstawionych powyżej okolicznościach można zdefiniować jako wyraz kontestacji panujących reguł i dążenie do przejęcia kontroli nad reprodukcją zinstytucjonalizowanej rzeczywistości publicznej i politycznej III RP.

Samoocena „Pokolenia 2000” budowana jest w odniesieniu do dyskursu wytwarzanego przez „Pokolenie '89”, który staje się w ten sposób kontrapunktem dla jej definicji tożsamościowych. Zasadniczym elementem dyskursu „Pokolenia 2000” jest żal owocujący krytycznymi ocenami ładu zalegitymowanego i zablokowanego przez „Pokolenie '89”. O ile „Pokolenie “68” zawłaszczyło dla siebie miejsca w polu polityki, tak „Pokolenie '89” zajęło przestrzeń sektora prywatnego, nie pozostawiając „Pokoleniu 2000” żadnego pola do zagospodarowania. W języku „Pokolenia 2000” te elementy przybierają formę obywatelskiego przypomnienia o społecznej współodpowiedzialności elit, czyli „Pokolenia '89”, za symboliczny i instytucjonalny pejzaż rzeczywistości, systemową legitymizację tego stanu rzeczy, rzutującą na obecną sytuację młodych ludzi. Cechą wyróżniającą omawianego aktora zbiorowego jest wewnętrzne zróżnicowanie. W przypadku „Pokolenia 2000” można mówić o dwóch frakcjach: rozczarowa- 
nych i zaadaptowanych. W dyskursie tego pokolenia, oprócz wspomnianych dwóch frakcji, pojawiają się także grupy „blokersów” i „młodzieży z prowincji”; nie mówią one jednak głosem swoich reprezentantów, tylko się o nich opowiada. W ten sposób dochodzi do dyskursywnego utrwalenia dystansów i podziałów społecznych, które zaistniały jako konsekwencja procesu transformacji, a tym samym podkreślenia elitarnego charakteru dyskursu. Wobec podzielanego przez wszystkich rozczarowania przestrzenią publiczną III RP odnaleźć można różne strategie adaptacyjne do istniejących warunków. Mamy zatem ucieczkę w indywidualne prywatne kariery grupy deklarującej $\mathrm{w}$ dyskursie zadowolenie z własnej egzystencji, swego rodzaju ucieczkę w prywatność jedyną możliwą do zagospodarowania przestrzeń. W takim ujęciu nie może być mowy o powodzeniu żadnych projektów wspólnotowych. Z drugiej strony mamy rozczarowanych tą sytuacją, którzy, nie mogąc zrealizować własnych scenariuszy życiowych nawet $\mathrm{w}$ wymiarze prywatnym, dążą do poszerzenia przestrzeni dyskursywnej o inne niż ekonomiczno-rynkowe definicje rzeczywistości, a przez to uwolnienie potencjału młodzieży do jego realizacji w rozmaitych obszarach. Zablokowanie przestrzeni sektora polityki przez „Pokolenie “68” i sektora prywatnego przez „Pokolenie '89” skutkuje na poziomie „Pokolenia 2000” przeniesieniem życiowej aktywności w obszar kultury i uznaniem jej za zasadniczy fundament nowoczesnej tożsamości obywatelskiej, a tym samym faworyzacją systemu socjokulturowego. Nowym sposobem „poszerzenia świata życia” staje się emigracja.

\section{„POKOLENIE 2010”}

„Pokolenie 2010” w symboliczny sposób zamyka 20-letni okres transformacji - jego tożsamość jest wynikiem nowych mechanizmów reprodukcji społecznej oraz zmian, jakie dokonały się w społeczeństwie polskim, stanowiąc jednocześnie zwiastun jego przyszłego kształtu. Do zastanych przez uczestników debaty okoliczności należały w szczególności dwie zmienne: ekonomizacja „świata życia” oraz obietnica awansu przez edukację. Przekłada się to na zakres aktywności zawodowej, aspiracji, motywacji i pragnień jednostek, kształtując ich życiorysy. Komunikacja skoncentrowana wokół rematów awansu społecznego przez edukację oraz pozycję na rynku pracy staje się ramą dla „działań” dyskursywnych, które jedynie reprodukują zastany ład symboliczny. Wyłania się zatem obraz „wspólnoty” metrykalnej, która definiowana jest wyłącznie zewnętrznie, przez systemowe okoliczności zastane.

W debatach z udziałem „Pokolenia 2010” przedstawiciele elit symbolicznych próbowali uniwersalizować określony „obraz” pokolenia, nie mniej ważny niż autodefinicje młodzieży, bowiem stanowiący punkt odniesienia dla budowania tych ostatnich. W ten sposób dochodziło do próby wytwarzania młodym osobom określonego świata przedmiotów i pożądanych sposobów nadawania im znaczeń. Pojawiających się w dyskursie reprezentantów elit symbolicznych (tzw. głosy eksperckie) można podzielić na obóz niewspółodczuwający (reprezentowany najczęściej przez ekonomistów i polityków) i współodczuwający (socjologowie, artyści). Eksperci niewspółodczuwający mar- 
ginalizują pojawiające się problemy, sygnalizowane przez młodych w dyskursie. Wyraża się to w stosowanych przez tego aktora kliszach językowych: lepsza kiepska praca niż żadna, brać co jest, nie wybrzydzać czy nie doptacać do mtodych. Język ten jest używany w stosunku do elitarnej, wykształconej części młodzieży, która przez większość życia starała się zdobywać wszystkie edukacyjne szlify, mające, zgodnie z uniwersalizowanym mitem „awansu przez edukację”, pozwolić jej na osiągnięcie pozycji społecznej zgodnej z posiadanymi umiejętnościami i kwalifikacjami. Zatem odpowiedzialność za systemowe błędy zostaje w symboliczny sposób przeniesiona na jednostkę jako zarazem „reżysera” i „producenta” własnej biografii. Eksperci współodczuwający podkreślają z kolei niebagatelną moc naturalizowanych przekonań. Zasadnicza zmiana, jaka dokonała się na poziomie organizacji państwa, przyniosła także zmiany w procesach socjalizacyjnych i wychowawczych. Stąd pojawienie się pragmatyzacji, materializacji i indywidualizacji świadomości młodych ludzi. W takiej rzeczywistości ekonomia staje się zasadniczym medium interakcji społecznych. Powoduje to merkantylizację procesów budujących poziomy świata przeżywanego i dominację działań celowo-racjonalnych.

\section{PODSUMOWANIE}

Reguły definiowania rzeczywistości, jak pokazuje przegląd dyskursywnych przestrzeni tożsamościowych każdego wyróżnionego w tym dyskursie aktora, zaczynają być w coraz większym stopniu domeną aktywności indywidualnych. Każda kolejna scharakteryzowana generacja posiada coraz bardziej negatywne formuły samookreślające. Przeprowadzone analizy dyskursu są również świadectwem procesu zmian w systemie odniesień charakterystycznym dla kolejnych aktorów. Najogólniej proces ten scharakteryzować można jako przejście od postaw ideowych zbudowanych na tzw. „wielkich narracjach” do pragmatyzmu codzienności. „Pokolenie “68” jest aktorem, które swoją aktywność „rzuca” na plan tradycyjnego uczestnictwa w życiu społecznym. Przez ten zwrot rozumiem pojmowanie aktywności politycznej jako sedna aktywności ludzkiej, przy czym polityka jest tutaj domeną szeroko definiowanych spraw publicznych, próbą permanentnego czynnego uczestnictwa w kształtowaniu rzeczywistości. „Pokolenie '89” za cechę charakterystyczną swojego systemu reguł pozwalających na wspólne definiowanie rzeczywistości uznawało ironię wobec polityki elit solidarnościowych i wycofanie się w sferę prywatną. „Pokolenie 2000” jest w prasowym dyskursie młodzieży reprezentantem coraz dalej idących indywidualizacji pozwalających na „oswajanie” rzeczywistości społecznej zarówno w wymiarze symbolicznym, jak i materialnym. Wszystkie zastane presupozycje i rematy świadczą o niekwestionowanej dominacji subsystemu ekonomicznego, którego praktyki naturalizowane są w dyskursie tej generacji w różnych idiomach, odnoszących się do podstawowej dyspozycji oceniającej, zadowolenia bądź rozczarowania z instytucjonalnego, etycznego i estetycznego kształtu rzeczywistości III RP. Wszystkich łączy niekwestionowalna „oczywistość” tej dominacji, subaktorzy różnią się „wyłącznie” wektorem ocen opisywanej rzeczywistości. W przypadku „Pokolenia 2010” podkreślić należy obecność presupozycji świadczących o zin- 
ternalizowaniu przekonania o daremności buntu wobec materialnie zdefiniowanej rzeczywistości. Przedstawiciele tego pokolenia posługują się regułami definicyjnymi, które w znacznym stopniu implikują konieczność zaakceptowania rynkowych mechanizmów podaży i popytu jako podstawowego regulatora życia społecznego.

Analizy są także świadectwem postępującej dekonstrukcji diapazonu narzędzi kulturowych, z pomocą których młodzież mogłaby autodefiniować się w kategoriach wspólnoty wyobrażonej. „Pokolenie '89” podkreśla publiczną „cenzurę” tego instrumentarium, która nałożona została przez „Pokolenie “68”. „Pokolenie 2000” najwięcej miejsca poświęca dyskursowi o atrofii tego instrumentarium, jednocześnie podkreślając „oczywistość” indywidualistycznych definicji rzeczywistości. „Pokolenia 2010” nie zajmuje już prawie w ogóle dyskurs o ,jakims'” wspólnotowym instrumentarium symbolicznym; jest ono nazbyt zajęte ucieczką w prywatność wraz ze wszystkimi jej problemami i uciechami.

Polski dyskurs prasowy młodzieży oraz o młodzieży, ze wszystkimi ujawnionymi w nim jej „obrazami”, jest raczej metanarracją o świecie, gdzie kolejne scharakteryzowane generacje, zarówno „same”, jak i pod wpływem wywołanych medialnie rematów, orientują się w swoim języku na systemową totalność ekonomiczną.

\section{BIBLIOGRAFIA}

Bauman Z., Koniec orgii, rozm. popr. T. Kwaśniewski, [w:] Twarze „Dużego Formatu”, Warszawa 2009, s. 12.

Beck U., Giddens A., Lash S., Modernizacja refleksyjna. Polityka, tradycja i estetyka w porzadku spotecznym nowoczesności, przeł. J. Konieczny, Warszawa 2009, Socjologia Wspótczesna Wydawnictwo Naukowe PWN.

Domański H., Merytokracja w zasadach dystrybucji wynagrodzeń w latach 1982-2005, [w:] Zmiany stratyfikacji spotecznej w Polsce, red. H. Domański, Warszawa 2008.

Giddens A., Nowoczesność i tożsamość. „Ja” i spoteczeństwo w epoce późnej nowoczesności, przeł. A. Szulżycka, Warszawa 2006, Biblioteka Socjologiczna.

Giddens A., Stanowienie spoteczeństwa. Zarys teorii strukturacji, przeł. S. Amsterdamski, Poznań 2003.

Krzemiński I., Socjologiczne przemiany wspótczesnego świata, [w:] Socjologia a przemiany wspótczesnego świata, red. I. Krzemiński, Warszawa 2004.

Mannheim K., The Problem of Generations, [w:] K. Mannheim, Essays on the Sociology of Knowledge, London 1952.

Mason P., Why It's Kicking Off Everywhere: the New Global Revolutions, London-New York 2012.

Messyasz K., Obrazy mtodzieży polskiej w dyskursie prasowym. Mtodzież o sobie i rzeczywistości spotecznej, Łódź 2013.

Mills Wright C., Wyobraźnia socjologiczna, przeł. M. Bucholc, red. nauk. i przedm. J. Mucha, Warszawa 2007, Biblioteka Socjologiczna.

Mtodzież 2003, „Opinie i Diagnozy” 2004, nr 2. 
Mtodzież 2008, „Opinie i Diagnozy” 2009, nr 13.

Moscovici S., The Phenomenon of Social Representations, [w:] Social Representations, eds. R. M. Farr,

S. Moscovici, Cambridge-New York-Paris 1984.

Moscovici S., Social Representations: Explorations in Social Psychology, ed. G. Duveen, New York 2001.

Rocznik demograficzny, Warszawa 2010.

Szafraniec K., Mtodzi 2011, red. nauk. M. Boni, Warszawa 2011.

Szlendak T., Supermarketyzacja. Religia i obyczaje seksualne mtodzieży w kulturze konsumpcyjnej, Wrocław 2008, Acta Universitatis Wratislaviensis, nr 3042.

Ziółkowski M., Globalizacja a przemiany struktury spotecznej we wspótczesnej Polsce, [w:] Spoteczne problemy globalizacji, red. nauk. Z. Blok, Poznań 2001, Cztowiek i Spoteczeństwo Uniwersytet im. Adama Mickiewicza w Poznaniu. Wydziat Nauk Spotecznych, t. 19.

Dr Karolina MESSYASZ - socjolog, adiunkt w Katedrze Socjologii Polityki i Moralności IS UŁ. Zainteresowania badawcze aktualnie koncentrują się na obszarze socjologii młodzieży, socjologii polityki, wpływie dyskursu publicznego na funkcjonowanie społeczeństwa oraz zarządzaniu w sferze kultury i polityki. 